ISSN 0258-7122

Bangladesh J. Agril. Res. 39(1): 151-163, March 2014

\title{
EFFECT OF DIFFERENT IRRIGATION AND TILLAGE METHODS ON YIELD AND RESOURCE USE EFFICIENCY OF BORO RICE (Oryza sativa)
}

\author{
M. R. KARIM ${ }^{1}$, M. M. ALAM ${ }^{2}$, J. K. LADHA ${ }^{3}$ \\ M. S. ISLAM ${ }^{4}$ AND M. R. ISLAM ${ }^{4}$
}

\begin{abstract}
An experiment was carried out in Bangladesh Agricultural Research Institute (BARI) farm during 2010-11 to evaluate yield and resource use efficiency of transplanted boro rice under two tillage and three irrigation methods. Two tillage methods viz., conventional tillage with puddle transplanted rice and reduced tillage unpuddled transplanted rice and three irrigation methods viz., sprinkler irrigation, alternate wetting and drying (AWD) and flood irrigation were used as treatment variables. Grain yield was $7.62 \%$ higher in sprinkler and $4.72 \%$ higher in AWD irrigation method over flood irrigation method. Irrespective of tillage methods, reduced tillage method holds $4.62 \%$ higher yield production over conventional tillage method. Water use efficiency was found highest in sprinkler irrigation method $\left(0.83 \mathrm{~kg} / \mathrm{m}^{3}\right)$ and in reduced tillage method $\left(0.773 \mathrm{~kg} / \mathrm{m}^{3}\right)$. Labour required for land preparation was $15 \mathrm{md} / \mathrm{ha}$ in reduced tillage, whereas it was $38 \mathrm{md} / \mathrm{ha}$ in conventional tillage method. Seedling uprooting and transplanting required higher labour in reduced tillage method over conventional tillage. Fuel consumptions (49.78 1/ha) and electricity (3475.11 Kwhr/ha) was also less in reduced tillage method. Reduced tillage had less land preparation and fuel cost over conventional tillage method. But seedling uprooting and transplanting cost was higher in reduced tillage. Irrigation and total cost of production was $7753 \mathrm{Tk}$./ha and $69972 \mathrm{Tk}$./ha in Sprinkler $\times$ RT method. Benefit cost ratio was also higher in sprinkler irrigation (1.81) and reduced tillage method (1.82).
\end{abstract}

Keywords: Reduced tillage, sprinkler irrigation, water use efficiency, yield.

\section{Introduction}

Water is becoming increasingly scarce worldwide and more than one-third of the world population would face absolute water scarcity by the year 2025 (Seckler $e t$ al., 1999 and Rosegrant et al., 2002). The worst affected areas would be the semi-arid regions of Asia, the Middle-East, and sub-Saharan Africa, all of which are already having a heavy concentration of population growth and their living below poverty line. With this faster population growth in this region, future water use has been declining at a faster rate and requirement of food and other

${ }^{1}$ BRAC, 75 Mohakhali, Dhaka 1212, Bangladesh ${ }^{2}$ International Rice Research Institute, Bangladesh Office, ${ }^{3}$ International Rice Research Institute (IRRI), India Office, ${ }^{4}$ Professor, Bangabandhu Sheikh Mujibur Rahman Agricultural University (BSMRAU), Bangladesh 
agricultural commodities has been increasing. At present, rice is the staple food for more people than wheat, and 90 percent of total rice production is grown and consumed in Asia (Evans, 1998). In Bangladesh, people also consumed rice as staple food and it constituted about $90 \%$ of the total food grain production (Huda, 2001). Of the three types of rice Aus (Early monsoon rice), Aman (Monsoon rice) and Boro (Dry season rice), the Boro rice alone contributed the highest share of total rice production since 1998-99 to date (BER, 2005). Therefore, increase of Boro rice production would be a significant possible way to overcome food deficiency in the country. Boro rice production in the 2007-2008 season amounted to 17.8 million tons (BBS, 2009), which is over $60 \%$ of the total annual rice production in Bangladesh (Hossain, 2009). Thus, the production of dry season irrigated rice has a predominant importance for national food security (Fujita, 2004). Boro rice is grown in the rabi season (November to May) and it grows totally under irrigated condition. The method used by our farmers to irrigate their fields are flood irrigation method. They usually use ground water using shallow and deep tube wells. The application of ground-water irrigation increased with the introduction of high yielding variety (HYV) seeds to meet the food requirements of a growing population (BER, 2005). Continuous lifting water for irrigation resulting in ground water depletion day by day. Researchers found that to grow rice plant, water does not require stagnate over growing period. So there is a method named Alternate Wetting and Drying (AWD), keeping soils at saturation, and alternate wetting and drying systems. Researchers in China found that AWD significantly reduced water input and increased yields (Li, 2001). Bouman and Tuong (2001) also reported that AWD in the tropics reduced water input, but yields usually declined when the soil water potential (SWP) during the non-submerged phase reached values between -10 and -40 $\mathrm{kPa}$. On the other hand, recently, there have been attempts to adopt pressurized irrigation methods to grow rice and wheat in various countries (Spanu et al., 1996). Sprinkler systems, such as portable rain guns can be used to apply a desired depth of water during pre sowing and subsequent irrigations. The application of irrigation water with sprinklers has improved on-farm irrigation efficiencies up to $80 \%$ under the prevailing climatic conditions in the Indian Subcontinent (Sharma, 1984).

In Asia, rice is commonly grown by transplanting seedlings into puddle soil (Land preparation with wet tillage). Puddling benefits rice by reducing water percolation losses, controlling weeds, facilitating easy seedling establishment, and creating anaerobic conditions to enhance nutrient availability (Sanchez, 1973). But, repeated puddling adversely affects soil physical properties by destroying soil aggregates, reducing permeability in subsurface layers, and forming hard-pans at shallow depths (Aggarwal et al., 1995; Sharma and De 
Datta, 1985; Sharma et al., 2003). All of which can negatively affect the following non-rice upland crop in rotation (Hobbs and Gupta, 2000; Tripathi et al., 2005). Moreover, puddling and transplanting require huge amount of water and labour, both of which are becoming increasingly scarce and expensive, making rice production less profitable. So considering all these things, there is a need to develop appropriate irrigation and tillage method to cope with this problem that will be economically feasible and environmentally sustainable.

\section{Materials and Method}

A field experiment was conducted at the Experimental Farm of the Bangladesh Agricultural Research Institute (BARI), Joydebpur, Gazipur during Boro season from December 2010 to May 2011. The soil of experimental farm belongs to Madhupur Tract in Agro, ecological zone (AEZ) 28. Bulk density of soil varies here with depth up to $30 \mathrm{~cm}$. Bulk density of soil is $1.0535,1.0788,1.1388$, $1.1714,1.1377$ and $1.1239 \mathrm{gm} / \mathrm{cc}$ of 0-5, 6-10, 11-15, 16-20, 21-25, and 26-30 $\mathrm{cm}$ depth, respectively. The total rainfall of the locality during the crop growing period was $2.73 \mathrm{~mm}$ only. The daily evaporation during the growing season ranges from 0.82 to $2.92 \mathrm{~mm}$. The average maximum air temperature lies between $23.7^{\circ} \mathrm{C}$ and $33.1^{\circ} \mathrm{C}$ and minimum air temperature between $10.3^{\circ} \mathrm{C}$ and $23.4^{\circ} \mathrm{C}$ during the experimentation. The daily average relative humidity during season was mostly between 45 to $90 \%$.

The treatment of the experiment were three irrigation methods viz., Sprinkler irrigation, Alternate Wetting and Drying (AWD), and Flood irrigation and two tillage methods viz., conventional tillage (Puddled transplanted rice with integrated crop and resource management practices) and reduced tillage (Unpuddled transplanted rice with integrated crop and resource management practices). The experiment was laid out in two factors Randomized Complete Block Design with three replications. The plot size was $16 \mathrm{~m} \times 12 \mathrm{~m}$. The total numbers of treatments were six.

The seeds were treated with Bavistin at the rate of $112 \mathrm{~g} / \mathrm{ha}$ area equivalent to $3.75 \mathrm{~g} / \mathrm{kg}$ of seeds before sowing. Seeds of BRRI dhan 28 were sown during Rabi season in 2010-2011 in an ideal raised seed bed. First the land was ploughed properly ( 5 pass with power tiller) and levelling. Then the beds were raised in 32 $\mathrm{cm}$ long and wide of each bed were 1.25 meter and gap between two beds were $30 \mathrm{~cm}$ apart which were used for drainage purpose. Fertilizer rate as a basal dose were $100 \mathrm{~g} \mathrm{P}, 134 \mathrm{~g} \mathrm{~K}$, and $155 \mathrm{~g} \mathrm{~N}$ for $40 \mathrm{~m}^{2}$ area of seed bed and seeding rate in seed bed were $4 \mathrm{~kg}$ seed in $40 \mathrm{~m}^{2}$ areas. Seed beds were kept continuous wetted until seedling uprooting. For both conventional tillage (CT) and reduced tillage 
(RT), fertilizers at the rate of 144-20-85-10-2 kg/ha of N, P, K, S, and Zn were applied in the form of urea, TSP, MoP, gypsum, and zinc sulphate, respectively. Total TSP, gypsum, zinc sulphate, and two thirds MoP were applied during final land preparation and thoroughly incorporated with the soil. Urea was applied as top dress during 15 days after transplanting (DAT), maximum tillering stage (MTS) and before panicle initiation (PI) stage. The remaining MoP was applied with urea before PI stage. Thirty seven days old seedlings were transplanted on 12 January 2011 with 2-3 seedlings in each hill in both CT and RT treatments. Both plant to plant and row to row distances were maintained $20 \mathrm{~cm}$. Gap filling was done with even aged seedlings within two weeks after transplanting.

In flood irrigation method, 5-7 $\mathrm{cm}$ of standing water was maintained by adding irrigation water at 3-4 days interval based on soil condition until ripening as per practices followed by rice farmers. No soil cracking is allowed in this irrigation method. In AWD method, irrigation was done following alternate wetting and drying (AWD) technique. It is done by installing a perforated PVC pipe in the rice field to observe water level. In each time of irrigation, standing water of 4-5 cm was maintained. Irrigation was continued up to one week before flowering and 3-5 $\mathrm{cm}$ of standing water was kept from flowering stage to two weeks before harvesting. In sprinkler irrigation method, $2-3 \mathrm{~cm}$ standing water was maintained throughout the season. It is a rain port micro sprinkler system. In each experimental unit, 20 micro sprinklers were installed. The operating pressure required for this system is $1 \mathrm{~kg} / \mathrm{cm}^{2}$. The radius of application of each sprinkler was $3.70 \mathrm{~m}$ and discharge rate was $140 \mathrm{l} / \mathrm{hr}$. In this irrigation method, irrigation decision was taken based on AWD method but water was applied in sprinkler irrigation system with lower water level. Soil stirring was done 25 days after transplanting (DAT) by hand. It helped to increase the soil aeration. Suntap was applied twice in the entire growing season at 40 DAT and 83 DAT, respectively, at the rate of $1.6 \mathrm{~kg} / \mathrm{ha}$. Perching was used as a biological control agent. The cost and return analysis were done to compare the economic benefit for differential crop and resource management in Boro rice in terms of total variable costs, gross return, gross margin, and benefit cost ratio (BCR). Data recorded on different parameters were subjected to analysis of variance (ANOVA) by using MSTAT-C program to examine the significant variation of the results based on different treatments. The treatment means were compared by LSD at 5\% level of significance.

\section{Results and Discussion}

Yield and yield component: Irrigation had significant effect on number of grains/panicle and grain yield, but found insignificant in number of tillers $/ \mathrm{m}^{2}$, 
number of panicles $/ \mathrm{m}^{2}$, number of filled grains/panicle, number of unfilled grains/panicle, 1000-grain weight and straw yield (Table 1).

Table 1. Effect of irrigation and tillage methods on yield and yield component of BRRI dhan28.

\begin{tabular}{l|c|c|c|c|c|c|c|c}
\hline Treatment & $\begin{array}{c}\text { Tillers/ } \\
\mathrm{m}^{2} \\
\text { (no.) }\end{array}$ & $\begin{array}{c}\text { Panicles/ } \\
\mathrm{m}^{2} \\
\text { (no.) }\end{array}$ & $\begin{array}{c}\text { Grains } \\
\text { /panicle } \\
\text { (no.) }\end{array}$ & $\begin{array}{c}\text { Filled } \\
\text { grains } \\
\text { /panicle } \\
\text { (no.) }\end{array}$ & $\begin{array}{c}\text { Unfilled } \\
\text { grains } \\
\text { /panicle } \\
\text { (no.) }\end{array}$ & $\begin{array}{c}1000- \\
\text { grain } \\
\text { wt (g) }\end{array}$ & $\begin{array}{c}\text { Straw } \\
\text { yield } \\
\text { (t/ha) }\end{array}$ & $\begin{array}{c}\text { Grain } \\
\text { yield } \\
\text { (t/ha) }\end{array}$ \\
\hline Irrigation methods & & & & & & & & \\
Flood & 336 & 293 & 99 & 91 & 9 & 20.05 & 4.64 & 5.45 \\
AWD & 342 & 296 & 100 & 91 & 9 & 20.58 & 4.57 & 5.72 \\
Sprinkler & 343 & 299 & 104 & 93 & 7 & 21.11 & 4.58 & 5.9 \\
LSD(0.05) & $\mathrm{Ns}$ & $\mathrm{Ns}$ & 4.90 & $\mathrm{Ns}$ & $\mathrm{Ns}$ & 0.74 & $\mathrm{Ns}$ & 0.24 \\
Tillage methods & & & & & & & & \\
CT & 338 & 292 & 99 & 91 & 9 & 20.38 & 4.51 & 5.55 \\
RT & 341 & 300 & 104 & 92 & 8 & 20.77 & 4.67 & 5.82 \\
\hline LSD $(0.05)$ & $\mathrm{Ns}$ & $\mathrm{Ns}$ & 4.00 & $\mathrm{Ns}$ & $\mathrm{Ns}$ & $\mathrm{Ns}$ & $\mathrm{Ns}$ & 0.19 \\
CV $(\%)$ & 4.28 & 5.07 & 3.76 & 2.38 & 26.62 & 2.81 & 5.76 & 3.29 \\
\hline
\end{tabular}

Ns = Not significant, AWD = Alternate wetting and drying,

$\mathrm{CT}=$ Conventional tillage and $\mathrm{RT}=$ Reduced tillage

The highest number of grains/panicle was observed in sprinkler irrigation method (104) followed by that of AWD (100) and flood irrigation method (99). Similar trend was found in respect of tillage methods. Reduced tillage (104) had more grains/panicle over conventional tillage (99) method. In irrigation context, sprinkler irrigation $(5.90 \mathrm{t} / \mathrm{ha})$ had the highest yield over AWD (5.72 t/ha) and flood irrigation $(5.45 \mathrm{t} / \mathrm{ha})$ method. On the contrary, reduced tillage $(5.82 \mathrm{t} / \mathrm{ha})$ yielded maximum over conventional tillage $(5.55 \mathrm{t} / \mathrm{ha})$ method. Similar result was observed by Kahlown et al. (2007). They reported that flood irrigation system produced up to $31 \%$ less rice than the sprinkler irrigated fields possibly due to excessive leaching of nutrients. On the other hand, many studies have shown that AWD can be managed to maintain grain yield in rice (De Dios et al., 2000) and that it sometimes even leads to an increase in yield (Yang et al., 2007). Yield benefit from AWD have been ascribed to better root vigour and depth (Mao et al., 2000); reduce lodging, pests and disease (Yi. 1999); better soil oxygenation (Wang, 1999), reduce lodging in wet seeded rice in Vietnam (T. P. Tuong, pers. comm.) and increase tillering and panicle density in Bangladesh (E. Humphreys, pers. comm.). They also argued that the higher yield in AWD was primarily due to higher root oxidation activity, cytokinin concentration in roots and shoots, leaf photosynthesis rate, and activities of key enzymes involved in sucrose-to- starch conversion in grains. Ohiri and Ezumah (1990) reported that, 
tillage did not affect total bio-mass yields during the first year; but in the second year, significant differences were obtained in the yield of tops but not of fresh roots. They also reported that no-till and minimum tillage yielded 40 and $23 \%$ more tops than conventional tillage. However, interaction effect of irrigation and tillage methods on yield didn't found significant.

Water use and water-use efficiency: Water use and water-use efficiency was significantly influenced by irrigation and tillage method (Table 2). In case of irrigation method, total numbers of irrigation, total amount of water used including rainfall and water use efficiency were significantly different among all treatments.

Table 2. Effect of Irrigation and tillage methods on water use and water use efficiency of BRRI dhan28

\begin{tabular}{l|c|c|c|c|c}
\hline Treatment & $\begin{array}{c}\text { Total no. of } \\
\text { irrigations }\end{array}$ & $\begin{array}{c}\text { Total amount } \\
\text { of irrigation } \\
\text { water received } \\
(\mathrm{mm})\end{array}$ & $\begin{array}{c}\text { Total amount } \\
\text { of rainfall } \\
\text { received } \\
(\mathrm{mm})\end{array}$ & $\begin{array}{c}\text { Total amount } \\
\text { of water } \\
\text { received } \\
(\mathrm{mm})\end{array}$ & $\begin{array}{c}\text { Water use } \\
\text { efficiency } \\
\left(\mathrm{kg} / \mathrm{m}^{3}\right)\end{array}$ \\
\hline Irrigation methods & 16 & 590 & 324 & 914 & 0.598 \\
Flood & 14 & 452 & 324 & 776 & 0.738 \\
AWD & 18 & 389 & 324 & 713 & 0.830 \\
Sprinkler & 18 & 12.78 & $\mathrm{Ns}$ & 12.78 & 0.04 \\
LSD $(0.05)$ & 0.30 & & & & \\
Tillage methods & & 508 & 332 & 840 & 0.671 \\
CT & 15 & 446 & 316 & 762 & 0.773 \\
RT & 16 & 10.42 & $\mathrm{Ns}$ & 10.42 & 0.03 \\
\hline LSD $(0.05)$ & 0.25 & 2.08 & - & 1.24 & 4.05 \\
CV $(\%)$ & 1.49 & & & & \\
\hline
\end{tabular}

Ns $=$ Not significant, $\mathrm{AWD}=$ Alternate wetting and drying,

$\mathrm{CT}=$ Conventional tillage and $\mathrm{RT}=$ Reduced tillage

The highest number of irrigation (18) was needed in sprinkler irrigation method followed by flood (16) and alternate wetting and drying (14) method. Sprinkler irrigation method required highest number of irrigation because amount of water applied was less than other methods. The highest water use was observed in flood irrigation method $(914 \mathrm{~mm})$ followed by that of AWD (776 $\mathrm{mm})$ and the lowest was recorded in sprinkler irrigation method $(713 \mathrm{~mm})$ and all were significantly different from each other. AWD irrigation method recorded $15.09 \%$ less irrigation water over flood irrigation and sprinkler irrigation method recorded $21.96 \%$ less over flood irrigation water. Sprinkler method recorded the lowest water use than other methods due to its uniform distribution of water 
across the field. As a result, water use efficiency was maximum in sprinkler irrigation followed by AWD and flood irrigation method. Kulkarni (2005) and INCID (1998) reported that sprinkler irrigation method has relatively less water saving (up to $70 \%$ efficiency) since it supplies water over the entire field of the crop. Similar result was reported by McCauley (1990). The experiments used commercial lowland rice cultivars using sprinkler irrigation method. Irrigation water requirements were $20-50 \%$ less than in flooded conditions, depending on soil type, rainfall and water management.

Water use and its efficiency were significantly different between tillage methods. Number of irrigation was more in reduced tillage (RT) than conventional tillage (CT). This might be due to higher infiltration rate in reduced tillage system. Water use was also recorded lower in RT $(762 \mathrm{~mm})$ method than CT $(840 \mathrm{~mm})$ method, which is $9.25 \%$ less over CT method. This is because, in reduced tillage system, irrigation water did not stagnate longer time as practices for conventional tillage system for puddling purpose. In reduced tillage system, land was prepared using Power Tiller Operated Seeder (PTOS) with two passes. Then irrigation water was entered into plot and transplanting was done without pudding and levelling. Amount of rainfall received was lower in reduce tillage $(316 \mathrm{~mm})$ method than conventional tillage $(324 \mathrm{~mm})$ due to early flowering as well as early maturity. Water use efficiency was also recorded highest in reduced tillage method.

Major resource used: Effect of irrigation and tillage method on major resource needed by BRRI dhan 28 is presented in Table 3. There was no significant difference among irrigation methods on labour for land preparation, seedling uprooting, and transplanting as well as total labour during cropping season duration, and fuel consumption during land preparation except electricity used in irrigation purpose. Electricity consumption was found highest (4593.00 Kwhr/ha) in flood irrigation method due to highest amount of irrigation water used. Besides, sprinkler irrigation method consumed the lowest $(3015.66 \mathrm{Kwhr} / \mathrm{ha}$ ) electricity for the lowest water used. Tillage method had significant difference on all the resources needed by BRRI dhan28 except total labor during crop season (Table 3). Labor required for land preparation was observed highest (38.56 $\mathrm{md} / \mathrm{ha}$ ) in conventional tillage (CT) system. Conventional tillage system mainly involved 6 passes with power tiller in addition with soil puddling and leveling. On the contrary, reduced tillage (RT) system found $15.11 \mathrm{md} / \mathrm{ha}$ for land preparation because it required only 2 passes using PTOS without soil puddling and levelling. 
Table 3. Effect of irrigation and tillage methods on major resources needed for BRRI dhan28.

\begin{tabular}{|c|c|c|c|c|c|}
\hline Treatment & $\begin{array}{l}\text { Labour } \\
\text { required for } \\
\text { land } \\
\text { preparation } \\
(* \mathrm{md} / \mathrm{ha})\end{array}$ & $\begin{array}{l}\text { Labour } \\
\text { required for } \\
\text { seedling } \\
\text { uprooting \& } \\
\text { transplanting } \\
(\mathrm{md} / \mathrm{ha})\end{array}$ & $\begin{array}{l}\text { Total labour } \\
\text { required for } \\
\text { crop season } \\
(\mathrm{md} / \mathrm{ha})\end{array}$ & $\begin{array}{c}\text { Fuel } \\
\text { consumpti } \\
\text { on (1/ha) }\end{array}$ & $\begin{array}{c}\text { Electricity } \\
\text { used } \\
\text { (Kwhr/ha) }\end{array}$ \\
\hline \multicolumn{6}{|c|}{ Irrigation methods } \\
\hline Flood & 26.83 & 53.00 & 193.50 & 54.70 & 4593.00 \\
\hline AWD & 25.17 & 52.83 & 193.33 & 55.56 & 3543.33 \\
\hline Sprinkler & 25.50 & 52.33 & 195.00 & 55.56 & 3015.66 \\
\hline $\operatorname{LSD}(0.05)$ & Ns & Ns & Ns & Ns & 120.80 \\
\hline \multicolumn{6}{|c|}{ Tillage methods } \\
\hline $\mathrm{CT}$ & 38.56 & 45.66 & 197.33 & 60.76 & 3959.55 \\
\hline RT & 15.11 & 59.77 & 190.55 & 49.78 & 3475.11 \\
\hline $\operatorname{LSD}(0.05)$ & 1.81 & 2.48 & Ns & 3.09 & 98.56 \\
\hline $\mathrm{CV}(\%)$ & 6.67 & 4.48 & 4.65 & 5.34 & 2.53 \\
\hline
\end{tabular}

Ns $=$ Not significant and $*$ md $=$ Man-day, 1 man-day $=8$-hour working time for individual labour)

Labour required for seedling uprooting and transplanting was observed 59.77 $\mathrm{md} / \mathrm{ha}$ in reduced tillage method whereas conventional tillage needed 45.66 $\mathrm{md} / \mathrm{ha}$. Reduced tillage method required higher labour for transplanting due to its unpuddled condition of plot that made a labour to take a little bit more time to transplanting. Fuel and electricity use was also higher in conventional tillage system compared to reduced tillage system. Besides, total number of labour for both tillage methods was statistically similar with each other.

Comparative cost: Land preparation and fuel cost were found significantly difference between conventional and reduced tillage methods irrespective of irrigation methods (Table 4).

Results revealed that conventional tillage had double cost for land preparation over reduced tillage method. This happened due to conventional tillage involved 6 passes, water needed to stagnated there over long period for proper puddling and finally for land levelling. In contrast, reduced tillage needed only 2 passes with PTOS resulting in lower power tiller rent, no laddering as well as no land levelling was needed there, just water was entered and afterward transplanted. Fuel cost was also lower because of minimum tillage had done with only 2 passes in reduced tillage method. However, seedling uprooting and transplanting cost were significantly higher in reduced tillage method irrespective 
of irrigation methods. Reduced tillage method needed 1.5 times more transplanting time over conventional tillage method. This is because of having not well puddled land, labour needed more time to transplant seedling. Regarding irrigation cost, it was calculated on the basis of price per Kwhr (1 unit) at the rate of $2.75 \mathrm{Tk}$. The highest irrigation cost was recorded in conventional tillage $\times$ flood irrigation method followed by reduced tillage $\times$ flood irrigation, conventional tillage $\times$ AWD irrigation. However, reduced tillage $\times$ AWD irrigation and conventional tillage $\times$ sprinkler irrigation found insignificant to each other and the lowest irrigation cost was found in reduced tillage $\times$ sprinkler irrigation system. On the other hand, total cost of production was found significant to each treatment combination and recorded maximum in conventional tillage $\times$ flood irrigation system and minimum was found in reduced tillage $\times$ sprinkler irrigation combination system.

Table 4. Different cost of production as affected by interaction of tillage and irrigation methods of BRRI dhan 28 .

\begin{tabular}{|c|c|c|c|c|c|c|}
\hline \multicolumn{2}{|c|}{$\begin{array}{l}\text { Interaction of tillage } \\
\text { and irrigation } \\
\text { methods }\end{array}$} & $\begin{array}{c}\text { Land } \\
\text { preparation } \\
\text { cost } \\
(* \text { Tk./ha })\end{array}$ & $\begin{array}{c}\text { Fuel cost } \\
\text { (Tk./ha) }\end{array}$ & $\begin{array}{c}\text { Seedling } \\
\text { uprooting \& } \\
\text { transplanting } \\
\text { cost (Tk./ha) }\end{array}$ & $\begin{array}{l}\text { Irrigation } \\
\text { cost } \\
\text { (Tk./ha) }\end{array}$ & $\begin{array}{l}\text { Total cost } \\
\text { of } \\
\text { production } \\
\text { (Tk./ha) }\end{array}$ \\
\hline \multirow[t]{3}{*}{ CT } & Flood & 15292 & 2673 & 9166 & 13477 & 80302 \\
\hline & AWD & 14945 & 2673 & 9270 & 10355 & 76930 \\
\hline & Sprinkler & 15153 & 2673 & 8888 & 8832 & 76574 \\
\hline \multirow[t]{3}{*}{$\mathrm{RT}$} & Flood & 7554 & 2138 & 12013 & 11782 & 74187 \\
\hline & AWD & 7478 & 2215 & 11875 & 9133 & 71802 \\
\hline & Sprinkler & 7339 & 2215 & 12013 & 7753 & 69972 \\
\hline \multicolumn{2}{|c|}{$\operatorname{LSD}(0.05)$} & 572.80 & 236.50 & 771.40 & 469.10 & 3526 \\
\hline \multicolumn{2}{|c|}{$\mathrm{CV}(\%)$} & 2.79 & 5.35 & 4.02 & 2.52 & 2.59 \\
\hline
\end{tabular}

(*Tk= Bangladeshi currency, 1 US $\$=82.00 \mathrm{Tk}$ )

Cost of production and benefit cost ratio: Effect of irrigation and tillage methods on total variable cost, total return, net profit and benefit cost ratio are presented in Table 5. Total variable cost (TVC) was the highest (77245 Tk./ha) in flood irrigation method and it was statistically different from other two irrigation methods. This might be due to higher amount of water used in this method. AWD (74366 Tk./ha) and sprinkler (73274 Tk./ha) irrigation method gave statistically identical total variable cost. It was observed that total return was more in sprinkler (132775 Tk./ha) and AWD (128696 Tk./ha) irrigation method. These two irrigation methods appeared statistically similar. Flood (122634 Tk./ha) irrigation method observed the lowest return due to its low yield. 
Table 5. Effect of total variable cost, total return, net profit and BCR of BRRI dhan 28 as affected by irrigation and tillage method

\begin{tabular}{l|c|c|c|c}
\hline \multicolumn{1}{c|}{ Treatment } & $\begin{array}{c}\text { Total variable } \\
\text { cost (Tk./ha) }\end{array}$ & $\begin{array}{c}\text { Total return } \\
\text { (Tk./ha) }\end{array}$ & $\begin{array}{c}\text { Net profit } \\
\text { (Tk./ha) }\end{array}$ & $\begin{array}{c}\text { Benefit cost } \\
\text { ratio (BCR) }\end{array}$ \\
\hline Irrigation methods & \multicolumn{4}{|c}{} \\
Flood & 77245 & 122634 & 45389 & 1.59 \\
AWD & 74366 & 128696 & 54330 & 1.73 \\
Sprinkler & 73274 & 132755 & 59482 & 1.81 \\
LSD $_{(0.05)}$ & 2493 & 5437 & 5776 & 0.09 \\
Tillage methods & & & & \\
CT & 77936 & 124943 & 47008 & 1.60 \\
RT & 71987 & 131114 & 59126 & 1.82 \\
\hline LSD $(0.05)$ & 2035 & 4435 & 4715 & 0.074 \\
CV $(\%)$ & 2.59 & 3.30 & 8.46 & 4.10 \\
\hline
\end{tabular}

Net profit was also the highest in sprinkler irrigation method, which was statistically identical with AWD irrigation method. Flood irrigation method gave the lowest net profit. Consequently, benefit cost ratio (BCR) was found highest in sprinkler irrigation method and it was also statistically identical to AWD irrigation method. The lowest BCR was recorded in flood irrigation method. Different studies disclosed that sprinkler irrigation increases productivity by 20 to $90 \%$ for different crops (INCID, 1998); reduces weeds, soil erosion; cost of cultivation, especially in labour-intensive operations; energy use (electricity) for operating irrigation wells due to reduced water consumption (Narayanamoorthy, 2001).

Main effect of tillage method was significantly different between each other. Total variable cost showed the highest in conventional tillage (CT) system due to higher labour cost, involved more number of passes during land preparation, higher electricity cost during irrigation application, etc. Significant variation in total return, net profit, and benefit cost ratio were observed due to execution of tillage methods. These were observed highest in reduced tillage (RT) system.

\section{Conclusion}

Rice production significantly depends on most of the time on amount of irrigation and methods of tillage. Grain yield was $7.62 \%$ higher in sprinkler irrigation and $4.72 \%$ higher in AWD irrigation method over flood irrigation method. Reduced tillage also yielded $4.62 \%$ higher over conventional tillage method. Sprinkler irrigation and reduced tillage system may the option to shrink rice production cost. Water use efficiency and benefit cost ratio also higher in 
sprinkler irrigation and reduced tillage system. So, sprinkler irrigation and reduced tillage system may be the potential technology to cut cost of rice production and facilitate to achieve higher yield.

Acknowledgement: This paper is a part of MS dissertation of the first author. The author is grateful to IRRI-CSISA project for funding to conduct this experiment and Jain irrigation system Ltd. for providing necessary equipment.

\section{References}

Aggarwal, G. C., A. S. Sidhu, N. K. Sekhon, K. S. Sandhu, and H. S. Sur. 1995. Puddling and $\mathrm{N}$ management effects on crop response in a rice-wheat cropping system. Soil Till. Res. 36: 129-139.

BER (Bangladesh Economic Review). 2005. Bangladesh Economic Survey, Finance Division, Ministry of Finance, Government of Bangladesh, Dhaka, Bangladesh, 1207.

BBS, (Bangladesh Bureau of Statistics). 2009. Year Book of Agricultural Statistics of Bangladesh. Ministry of Planning. Government of Bangladesh.

Bouman, B. A. M. and T. P. Tuong. 2001. Field water management to save water and increase its productivity in irrigated lowland rice. Agric. Water Manage. 49: 11-30.

De Dios, J., A. A. Corpuz, A. J. Espritu, J. P. Quilang and M. D. Malabayabas. 2000. Controlled irrigation on transplanted lowland rice for efficient use of irrigation water. Philippine Rice R\&D highlights 1999. Department of Agriculture, Philippines Rice Research Institute, Maligaya, Munoz, Nueva Ecija, Pp.51-52.

Evans, L.T. 1998. Feeding the ten billion: plants and population growth. Cambridge University Press, Cambridge, UK, 247 P.

Fujita, K. 2004. Transformation of groundwater market in Bengal: Implications to efficiency and income distribution. Centre for Southeast Asian Studies, Kyoto University, Japan (Available at www.sasnet.lu.se/EASASpapers/ 8KoichiFujita.pdf, accessed 15.07.2010).

Hobbs, P. R. and R. K. Gupta. 2000. Sustainable resource management in intensively cultivated irrigated rice-wheat cropping systems of the Indo-Gangetic Plains of South Asia: Strategies and options. In "International Conference on Managing Natural Resources for Sustainable Production in 21st Century", 14-18 February 2000, New Delhi, India. Pp. 584-592.

Hossain, M. 2009. The impact of shallow tube wells and Boro rice on food security in Bangladesh. IFPRI Discussion Paper 917. International Food Policy Research Institute, Washington.

Huda, M. Z. 2001. Regional development of irrigation technologies and its impact on food grain production in Bangladesh, MS Thesis, Department of Agricultural Economics, BAU, Mymensingh, Bangladesh. 
INCID. 1998. Sprinkler irrigation in India. Indian National Committee on Irrigation and Drainage, New Delhi.

Kahlown, M. A., A. Raoof, M. Zubair and W. D. Kemper. 2007. Water use efficiency and economic feasibility of growing rice and wheat with sprinkler irrigation in the Indus Basin of Pakistan. Agricultural Water Management 87:292-298.

Kulkarni, S. A. 2005. Looking beyond eight sprinklers. Paper presented at the National Conference on Micro-Irrigation. G. B. Pant University of Agriculture and Technology, Pantnagar, India, June 3-5, 2005.

Li, Y. H. 2001. Research and practice of water-saving irrigation for rice in China. In R. Barker, R. Loeve, Y. Li and T.P. Tuong eds., Proc. Int. Workshop on Watersaving Irrigation for rice, 23-25 March 2001, Wuhan. Pp.135-144.

Mao, Z., Y. Li, T. P. Tuong, D. Molden and B. Dong. 2000. Water efficient irrigation regimes of rice in China. Paper presented at the International Rice Research Conference, Los Banos, Philippines.

McCauley, G.N. 1990. Sprinkler vs. flooded irrigation in traditional rice production regions of southeast Texas. Agronomy Journal 82: 677-683.

Narayanamoorthy, A. 2001. Impact of drip irrigation on sugarcane cultivation in Maharashtra. Agro-Economic Research Centre, Gokhale Institute of Politics and Economics, Pune, June.

Ohiri, A.C. and H. C. Ezumah. 1990. Tillage effects on cassava (Manihot esculenta) production and some soil properties. Soil Till Res. 17: 221-231.

Rosegrant, W. M., C. Ximing and S. A. Cline. 2002. World Water and Food to 2020: Dealing with Scarcity, International Food Policy Research Institute, Washington, D.C., USA and International Water Management Institute, Colombo, Sri Lanka.

Sanchez, P. A. 1973. Puddling tropical soils. Effects on water losses. Soil Sci. 115: 303 308.

Seckler, D., R. Barker and U. Amarasinghe. 1999. Water scarcity in twenty-first century. International Journal of Water Resources Development 15:1-2, Pp. 29-42.

Sharma, P. K., J. K. Ladha and L. Bhushan. 2003. Soil physical effects of puddling in rice-wheat cropping systems. In "Improving the Productivity and Sustainability of Rice-Wheat Systems: Issues and Impacts" (J. K. Ladha, J. E. Hill, J. M. Duxbury, R. K. Gupta, and R. J. Buresh, Eds.), Pp. 97-113. ASA, CSSA, SSSA, Madison, WI, ASA Special Publication 65.

Sharma, P. K. and S. K. De Datta. 1985. Effect of puddling on soil physical properties and processes. In Soil Physics and Rice, Pp. 217-234. International Rice Research Institute, Los Banos, Philippines.

Sharma, S. K. 1984. Principles and Practices of Irrigation Engineering. Oxford and IBH Publication Co., New York.

Spanu, A.G., P. R. Andria, A. Lavini and F. Q. Chiranda. 1996. Yield response of rice to increasing sprinkler irrigation. J. Int. Comm. Irri. Drain. 45: 56-66. 
Tripathi, R. P., P. Sharma and S. Singh. 2005. Tillage index: An approach to optimize tillage in rice-wheat system. Soil Till. Res. 80: 125-137.

Wang, G. 1999. Techniques of Shallow- exposed irrigation of rice and its popularization. In: Xu, Z. (Ed.), Proceedings of the International Symposium on Water-Saving Irrigation for Paddy Rice, Guilin, China, Pp.47-53.

Yang, C., L. Yang, Y. Yangand and Z. Ouyang. 2007. Rice root growth and nutrient uptake as influenced by organic manure in continuously and alternately flooded paddy soils. Agric. Water Manage. 70: 67-81.

Yi, Y., 1999. Shallow-exposed irrigation and irrigation of rice without water layer. In: $\mathrm{Xu}, \mathrm{Z}$. (Ed.), Proceeding of the International Symposium on Water-Saving Irrigation for Paddy Rice, Guilin, China. Pp. 163-167. 